\title{
Lidar observation of the 2011 Puyehue-Cordón Caulle volcanic aerosols at Lauder, New Zealand
}

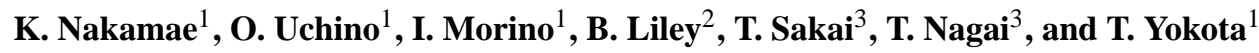 \\ ${ }^{1}$ National Institute for Environmental Studies, Tsukuba, Ibaraki, Japan \\ ${ }^{2}$ National Institute of Water and Atmospheric Research, Lauder, New Zealand \\ ${ }^{3}$ Meteorological Research Institute, Tsukuba, Ibaraki, Japan \\ Correspondence to: K. Nakamae (nakamae.kumi@nies.go.jp)
}

Received: 8 January 2014 - Published in Atmos. Chem. Phys. Discuss.: 23 May 2014

Revised: 18 September 2014 - Accepted: 23 September 2014 - Published: 18 November 2014

\begin{abstract}
On 4 June 2011, the Puyehue-Cordón Caulle volcanic complex $\left(40.6^{\circ} \mathrm{S}, 72.1^{\circ} \mathrm{W}\right)$ in Chile erupted violently and injected volcanic aerosols into the atmosphere. For the safety of civil aviation, continuous lidar observations were made at Lauder, New Zealand $\left(45.0^{\circ} \mathrm{S}, 169.7^{\circ} \mathrm{E}\right)$, from 11 June through 6 July 2011. The purpose of our study is to quantify the influence of the volcanic ejections from large eruptions, and we use the data from the ground-based lidar observation. We analyzed lidar data at a wavelength of $532 \mathrm{~nm}$ and derived the backscattering ratio and depolarization ratio profiles. During June and July, within the altitude range of $10-15 \mathrm{~km}$, the volcanic aerosols had high depolarization ratios (20-35\%), an indication of non-spherical volcanic ash particles. The time series of the backscattering ratio during continuous observations had three peaks occurring at about 12-day intervals: 26.7 at $11.2 \mathrm{~km}$ on 11 June, 18.1 at $12.0 \mathrm{~km}$ on 23 June, and 5.3 at $11.1 \mathrm{~km}$ on 6 July. The optical depth of the volcanic aerosols was 0.45 on 11 June, when the continuous lidar observation started, 0.31 on 23 June, and 0.12 on 6 July. The depolarization ratio values remained high up to a month after the eruption, and the small wavelength exponent calculated from the backscattering coefficients at $532 \mathrm{~nm}$ and $1064 \mathrm{~nm}$ suggests that a major constituent of the volcanic aerosols was large, non-spherical particles. The presence of volcanic ash in the stratosphere might affect the error in Greenhouse gases Observing SATellite (GOSAT) $\mathrm{XCO}_{2}$ retrieval using the $1.6 \mu \mathrm{m}$ band. We briefly discuss the influence of the increased aerosols on GOSAT products.
\end{abstract}

\section{Introduction}

Eruptions with a volcanic explosivity index (VEI) larger than 4 to 5 are generally expected to inject volcanic aerosols into the stratosphere (Newhall and Self, 1982; Deshler, 2008; Vernier et al., 2011; Trickl et al., 2013). The VEI was developed as a simple and semi-quantitative scheme for estimating the magnitude of historic eruptions by Newhall and Self (1982). Eruptions are assigned to a VEI on a scale of 0 to 8 , using the criteria such as the volume of ejecta, column height and qualitative of the eruption. Especially the volume of ejecta and the column height are important. Volcanic aerosol particles larger than $10 \mu \mathrm{m}$ injected into the stratosphere settle rapidly, so their climatic effects can generally be neglected (Robock, 2000). Volcanic ash is known to affect tropospheric cloud phases by acting as ice nuclei (Durant et al., 2008; Lathem et al., 2011). In contrast, when a large amount of sulfur dioxide is injected into the stratosphere, it is converted to sulfuric acid particles within several weeks (Zhao et al., 1995). The Mt. Pinatubo volcano (Philippines; $15.1^{\circ} \mathrm{N}, 120.4^{\circ} \mathrm{E}$ ) erupted on 15 June 1991 , and stratospheric injection of about $20 \mathrm{Mt}$ of $\mathrm{SO}_{2}$ was detected by the Total Ozone Mapping Spectrometer (Bluth et al., 1992). The $\mathrm{SO}_{2}$ is oxidized to sulfuric acid vapor from which sulfuric acid particles are produced by homogeneous nucleation (Wu et al., 1994). These particles are long-lived in the stratosphere (Uchino et al., 1995; Nagai et al., 2010), depending on the latitude and altitude of injection, and significantly affect the global climate and radiation budget and the ozone layer (Minnis et al., 1993; McCormick et al., 1995; AladosArboledas et al., 1997; Robock, 2000; Solomon et al., 2011). 
Large amounts of volcanic ash in the atmosphere can damage aircraft engines and raise flight safety concerns; as a result they can have significant consequences for air traffic. The volcanic hazards for aircraft have been recognized that are the stop of aviation engines, reduction of visibility and the damage to windshields due to volcanic ash (Bernard and Rose, 1990). For example, the ash plume from the eruption of the Eyjafjallajökull volcano $\left(63.63^{\circ} \mathrm{N}, 19.62^{\circ} \mathrm{W}\right.$; Iceland $)$ on 14 April 2010 disrupted air traffic over Europe. The small particles and trace gases such as $\mathrm{SO}_{2}$ from this eruption were transported over long distances (Tesche et al., 2010; Ansmann et al., 2010; Wiegner et al., 2012).

On 4 June 2011, the Puyehue-Cordón Caulle volcanic complex (hereafter PCCVC; $40.59^{\circ} \mathrm{S}, 72.11^{\circ} \mathrm{W}$ ) in Chile erupted and injected large amounts of volcanic ash particles into the atmosphere (VEI =3) (Dzierma and Wehrmann, 2012). This volcanic complex had previously erupted in May 1960 (Lara et al., 2004; Raga et al., 2013). The volcanic aerosol plumes traveled eastward from Chile via the prevailing westerlies and passed over New Zealand (Klüser et al., 2013). Because the Volcanic Ash Advisory Center (VAAC) in Wellington had forecast that a large volcanic aerosol plume would reach New Zealand, we performed continuous observations of volcanic aerosols with lidar at Lauder $\left(45.04^{\circ} \mathrm{S}, 169.68^{\circ} \mathrm{E}\right)$, New Zealand, and provided the observational data to the VAAC for the safety of civil aviation. The aerosol lidar system at Lauder is a two-wavelength polarization lidar. In this study, we used continuous lidar observational data observed at Lauder from 11 June through 6 July 2011.

We retrieved the backscattering ratios at 532 and $1064 \mathrm{~nm}$ and the depolarization ratio at $532 \mathrm{~nm}$, and we calculated the ratio of the backscattering coefficients at 532 and $1064 \mathrm{~nm}$. For meteorological data and derivation of the tropopause height required for the lidar data analysis, we used the twice-daily radiosonde data observed at Invercargill $\left(46.42^{\circ} \mathrm{S}, 168.33^{\circ} \mathrm{W}\right), 186 \mathrm{~km}$ southwest of Lauder. We use the tropopause height as the lowest level at which the temperature lapse rate is less than $2 \mathrm{~K} \mathrm{~km}^{-1}$ for higher levels within $2 \mathrm{~km}$ defined by the World Meteorological Organization (WMO).

In the next section, we describe the lidar system at Lauder. In Sect. 3, we present the analysis and results. We discuss the backscatter wavelength dependence in Sect. 4.

\section{Lidar system and data analysis}

Lidar measurement of stratospheric aerosols at Lauder was started in November 1992, owing to interest in the thenrecent eruption of Mt. Pinatubo (Uchino et al., 1995) and as a component of the nascent Network for the Detection of Stratospheric Change, subsequently the Network for the Detection of Atmospheric Composition Change. Though that system had only a single detector $(532 \mathrm{~nm})$, some depolar- ization measurements were made starting in November 1995. The system operated reliably for 17 years and recorded the decline of the Pinatubo aerosol to a minimum in the late 1990s (Nagai et al., 2010), followed by an increase in stratospheric aerosols by other volcanoes (Vernier et al., 2011; Uchino et al., 2012). In February 2009 this lidar system was updated for both daytime and nighttime observations of aerosols and clouds for Greenhouse gases Observing SATellite (GOSAT) product validation (Nagai et al., 2009). The updated system is a two-wavelength polarization lidar. In this study, we use lidar data obtained by continuous measurements from 11 June 2011 to 4 July 2011, with measurements made before and after this period for GOSAT product validation. The main lidar specifications are summarized in Table 1. The light source of the lidar system is a Nd:YAG laser with a second-harmonic generator: the laser thus operates at two wavelengths, 532 and $1064 \mathrm{~nm}$. The pulse repetition rate is $10 \mathrm{~Hz}$, and the transmitted energy is $150 \mathrm{~mJ}$ per pulse each wavelength. The receiving telescope has a diameter of $30.5 \mathrm{~cm}$. The signal at $1064 \mathrm{~nm}$ is detected with an analogue-mode avalanche photodiode (APD), and two polarization components of the signals at $532 \mathrm{~nm}$ are detected with three photomultiplier tubes (PMTs) from the near surface to a high altitude of $\sim 40 \mathrm{~km}$.

In this study, we used the Fernald method (Fernald, 1984), in which the lidar equation for retrieving vertical profiles of the aerosol backscatter coefficients from lidar signal intensity is solved by assuming an extinction-to-backscatter ratio (lidar ratio). We also assumed that there was no aerosol in the upper atmosphere at around $30 \mathrm{~km}$, and used the value from that altitude as a reference value by which to normalize the rest of the profile. The lidar ratio is an important parameter for obtaining profiles of the particle extinction coefficient from lidar signals to use for iterative correction of the backscatter profile. The lidar ratio $S$ is defined as the ratio of the extinction coefficient $\alpha$ to the backscattering coefficient $\beta$ :

$S=\frac{\alpha}{\beta}$.

We assumed $S$ to be $50 \mathrm{sr}$ at both 532 and $1064 \mathrm{~nm}$ in this study. The lidar ratio depends on particle properties such as their size distribution and shape. The backscattering ratio $R$ is defined as follows:

$R=\frac{\left(\beta_{\mathrm{A}}+\beta_{\mathrm{M}}\right)}{\beta_{\mathrm{M}}}$,

where $\beta_{\mathrm{A}}$ is the aerosol backscattering coefficient and $\beta_{\mathrm{M}}$ is the molecular backscattering coefficient. For a pure Rayleigh atmosphere $R=1.0$, and the backscatter signal from aerosols increases as $R$ becomes larger than 1.0. The molecular backscattering coefficient $\beta_{\mathrm{M}}$ was calculated by using the atmospheric density profiles obtained from radiosonde data launched at Invercargill $\left(46.45^{\circ} \mathrm{S}, 168.33^{\circ} \mathrm{W}\right)$ (Bucholtz, 1995). 
Table 1. Lidar system at Lauder, New Zealand.

\begin{tabular}{|c|c|c|}
\hline \multicolumn{3}{|c|}{ System after update (after 18 Feb 2009) } \\
\hline \multicolumn{3}{|c|}{ Transmitter } \\
\hline Laser & $\mathrm{Nd}: \mathrm{Y}$ & \\
\hline Wavelength & $532 \mathrm{~nm}$ & $1064 \mathrm{~nm}$ \\
\hline Pulse energy & $150 \mathrm{~mJ}$ & $150 \mathrm{~mJ}$ \\
\hline Pulse repetition & \multirow{2}{*}{\multicolumn{2}{|c|}{$\begin{array}{c}10 \mathrm{~Hz} \\
0.2 \mathrm{mrad}\end{array}$}} \\
\hline Beam divergence & & \\
\hline \multicolumn{3}{|c|}{ Receiver } \\
\hline Telescope type & \multicolumn{2}{|c|}{ Ritchey-Chrétien (advanced) } \\
\hline Wavelength & $532 \mathrm{~nm}$ & $1064 \mathrm{~nm}$ \\
\hline Telescope diameter & \multicolumn{2}{|c|}{$30.5 \mathrm{~cm}(12 \mathrm{inch})$} \\
\hline Field of view (full angle) & \multicolumn{2}{|c|}{$1.0 \mathrm{mrad}$} \\
\hline Band width (FWHM) & $0.28 \mathrm{~nm}$ & $0.34 \mathrm{~nm}$ \\
\hline Polarization measurement & Yes & No \\
\hline Number of receiving channel & 3 & 1 \\
\hline Detector & PMT & APD \\
\hline Signal processing & 12 bit $\mathrm{A} / \mathrm{D}+$ photon counting & 12 bit $\mathrm{A} / \mathrm{D}$ \\
\hline Time resolution & \multicolumn{2}{|c|}{$10 \mathrm{~s}(\max ), 5 \min ($ nominal) } \\
\hline Altitude resolution & \multicolumn{2}{|c|}{$7.5 \mathrm{~m}$} \\
\hline
\end{tabular}

The lidar transmits linearly polarized light at $532 \mathrm{~nm}$ and records the backscattering intensity with parallel $P_{\|}$and perpendicular $P_{\perp}$ polarization to the transmitted polarization. The total depolarization ratio $\delta$ is defined as

$\delta=\frac{P_{\perp}}{\left(P_{\perp}+P_{\|}\right)} \times 100 \%$.

Because backscattering by spherical particles does not change the laser polarization, $\delta=0$ for spherical particle. The depolarization ratio is sensitive to the non-spherical particles. When $\delta>0$, the scattering by non-spherical particles is recognized (Sassen, 1991).

\section{Results}

\subsection{Comparisons of aerosol vertical profiles before and after the eruption}

Figure 1 shows the vertical profiles of $R$ and $\delta$ before and after the PCCVC eruption. The first aerosol plume from the PCCVC eruption on 4 June 2011 was observed by lidar at Lauder at midnight on 11/12 June. The volcanic aerosol peak was located above the tropopause $(10.35 \mathrm{~km})$ on 11 June. The peak $R$ value at $532 \mathrm{~nm}$ was 26.7 at $11.23 \mathrm{~km}$, and the peak $\delta$ value at $532 \mathrm{~nm}$ was $16.0 \%$ at $10.3 \mathrm{~km}$. The maximum value of $R$ on 28 May (before the eruption) around $7 \mathrm{~km}$ was due to tropospheric aerosols; the maximum value of $R$ in the stratosphere was 1.09 at $16.03 \mathrm{~km}$.
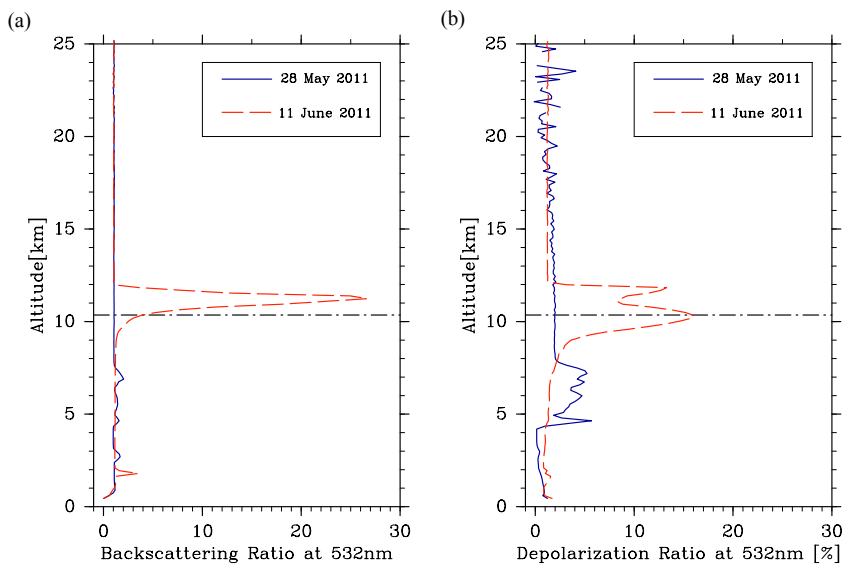

Figure 1. Vertical profiles of backscattering (left) and depolarization (right) ratios before (28 May, blue line) and after (11 June, red line) the PCCVC eruption on 4 June 2011. The horizontal dotdash line in each panel shows the tropopause height derived from radiosonde data at Invercargill.

The integrated backscattering coefficient (IBC) is defined by Eq. (4):

$\mathrm{IBC}=\int_{Z_{\mathrm{tr}}}^{Z_{\text {top }}} \beta_{\mathrm{A}} \mathrm{d} z$.

We calculated IBC from the tropopause height $Z_{\text {tr }}$ to $Z_{\text {top }}$, taking $Z_{\text {top }}=30 \mathrm{~km}$. IBC represents the amount of stratospheric aerosol loading at a given location. IBC was $2.2 \times$ $10^{-4} \mathrm{sr}^{-1}$ on $28 \mathrm{May}$; this value is slightly larger than the 
(a)

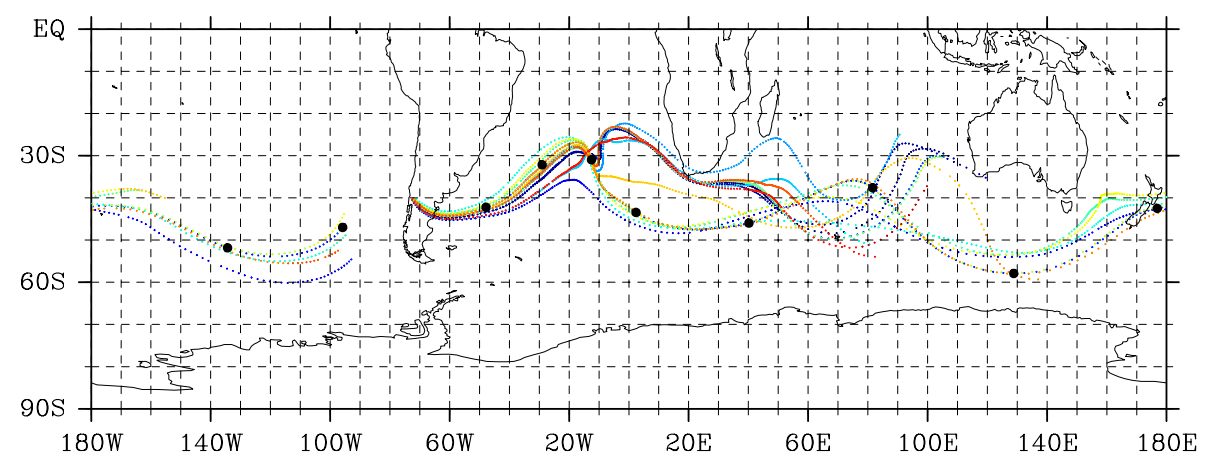

(b)

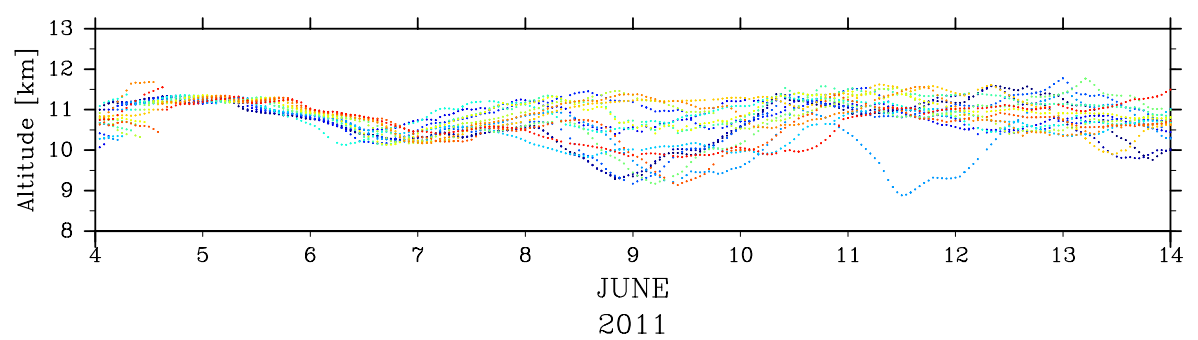

Figure 2. Ten-day isentropic forward trajectories of air parcels (colored lines) determined by using METEX. The starting position was the PCCVC $\left(40.59^{\circ} \mathrm{S}, 72.11^{\circ} \mathrm{W}\right)$, at $11 \mathrm{~km}$ above the surface. Large black dots mark each $24 \mathrm{~h}$ period in the simulation.

stratospheric background value of $1.42 \times 10^{-4} \mathrm{sr}^{-1}$ (Nagai et al., 2010). On 11 June, after the eruption, IBC was $8.5 \times$ $10^{-4} \mathrm{sr}^{-1}$; this value indicates that the PCCVC aerosols had reached the stratosphere over Lauder. We calculated forward trajectories to confirm that the observed profile peaks represented layers of volcanic aerosols derived from the PCCVC eruption. We calculated 10-day isentropic forward trajectories of air parcels by using the METEX (Meteorological Data Explorer) software package, which is provided by the National Institute for Environmental Studies and driven by NCEP/NCAR Reanalysis Data (Kalnay et al., 1996) four times daily (Fig. 2).

The initial points of 15 air parcels at $11 \mathrm{~km}$ altitude were located in a $1^{\circ} \times 1^{\circ}$ latitude/longitude box centered at the PCCVC eruption and released at 17:00 UTC on 4 June. The calculations showed that the air parcels leaving the volcano on 4 June 2011 reached Lauder in the early morning of 12 June. The calculations also showed that $43 \%$ of all air parcels reached the vicinity of Lauder, and the volcanic aerosol plume from the PCCVC eruption remained near the tropopause level in the mid-latitudes of the Southern Hemisphere. These results agree with the findings of Klüser et al. (2013), who used backward trajectory calculations and observations of the Infrared Atmospheric Sounding Interferometer (IASI) on board the MetOp satellite to determine the evolution of the ash plume around the Southern Hemisphere.

\subsection{Vertical profiles of the backscattering ratio and the depolarization ratio}

Vertical and temporal cross sections of the backscattering ratio and depolarization ratio at $532 \mathrm{~nm}$ over Lauder are presented in Fig. 3. Volcanic aerosol layers with a large backscattering ratio above the tropopause heights were distinguished from the cirrus clouds present at about 8-9 km altitude, simply by the position of the tropopause except when we could calculate $R$ at $1064 \mathrm{~nm}$, because we do not have enough signal-to-noise ratio to calculate $R$ at $1064 \mathrm{~nm}$ during most of the observation period. In each ratio, we observed three peaks above the tropopause height in the analysis period: on 11 June, 23 June, and 4 July. This result suggests that the volcanic aerosol plume circled the Southern Hemisphere three times, a finding that was confirmed by using IASI, Ozone Monitoring Instrument (OMI), and Moderate Resolution Imaging Spectroradiometer (MODIS) satellite data (not shown) (Klüser et al., 2013). To examine the three peaks of the aerosol vertical profiles in greater detail, we calculated the particle depolarization ratio $\delta_{\mathrm{p}}$, to estimate the non-sphericity of the particles:

$\delta_{\mathrm{p}}(z)=\frac{\delta(z) R(z)-\delta_{\mathrm{m}}}{R(z)-1} \times 100 \%$,

where $\delta$ is the total (molecular plus particle) depolarization ratio, calculated with Eq. (3), and $\delta_{\mathrm{m}}$ is the depolarization ratio of atmospheric molecules. We used $\delta_{\mathrm{m}}=0.37 \%$ for this lidar system, defined from the spectral transmission data of 
(a)

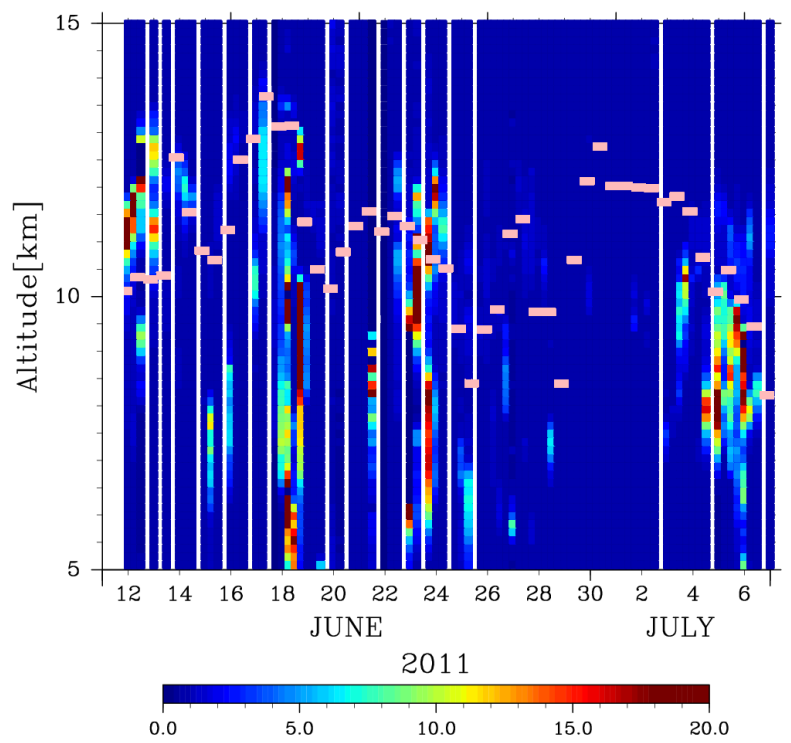

(b)

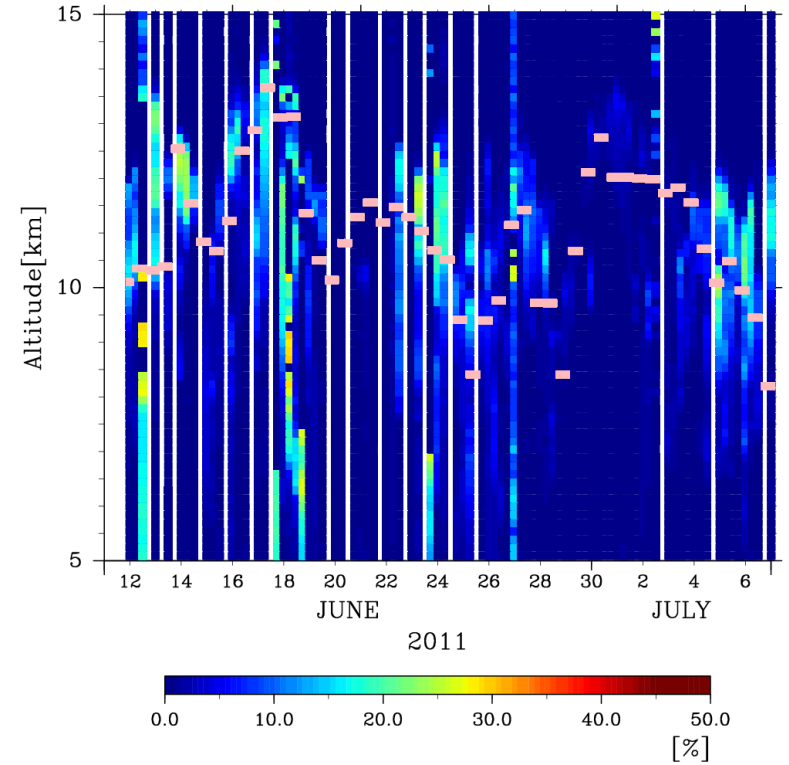

Figure 3. Vertical and temporal cross section of the backscattering ratio (a) and the depolarization ratio (b) at $532 \mathrm{~nm}$. The light purple rectangles show tropopause height.

the interference filter at $532 \mathrm{~nm}$ and the Rayleigh backscattering cross sections (Sakai et al., 2003). The measured $\delta$ was about $1.0-1.2 \%$ at altitudes higher than about $15 \mathrm{~km}$ (see Figs. 4a-c and 6), and this indicates that $\delta$ is the sum of $\delta_{\mathrm{m}}(0.37 \%)$ and the lidar system error (about $0.65 \%$ ) where there were no aerosols. We estimated $\delta_{\mathrm{p}}$ taking into account this lidar system error (Sakai et al., 2003). When $R$ is close to $1.0, \delta_{\mathrm{p}}$ has a larger error. For example, when $R=1.05$ and $\delta_{\mathrm{p}}=8 \%$, the error of $\delta_{\mathrm{p}}$ is larger than $20 \%$.
We estimated the proportion of non-spherical particles in the volcanic aerosol layers from the particle depolarization ratio over Lauder measured by lidar. On 11 June (Fig. 4a), the maximum values of $R, \delta$ and $\delta_{\mathrm{p}}$ were $26.7(11.2 \mathrm{~km})$, $16 \%(11.8 \mathrm{~km})$ and $19 \%(12.0 \mathrm{~km})$, respectively; on 23 June (Fig. 4b), they were $18.1(12.0 \mathrm{~km}), 25 \%(12.3 \mathrm{~km})$ and $32 \%$ $(12.4 \mathrm{~km})$, respectively; and on 6 July (Fig. $4 \mathrm{c})$, they were $5.3(11.1 \mathrm{~km}), 20 \%(11.4 \mathrm{~km})$ and $29 \%(11.7 \mathrm{~km})$, respectively. Values of $\delta_{\mathrm{p}}$ higher than $20 \%$ in the aerosol layer indicate a predominance of non-spherical particles (Sakai et al., $2003)$. The $\delta_{\mathrm{p}}$ values of the PCCVC volcanic aerosol layer were larger than $20 \%$ even on the third overpass during the continuous observation period. By comparison, the $\delta$ values of the Eyjafjallajökull volcanic aerosol layers in April 2010 in Iceland were 35-40\% (Ansmann et al., 2010; Gasteiger et al., 2011). According to the analysis by Groß et al. (2012), the wavelength-independent $\delta_{\mathrm{p}}$ values of the pure ash layer of the Eyjafjallajökull volcano were between 35 and $38 \%$.

One interesting feature of the depolarization data warrants further investigation. For each of the three overpass plume observations, $\delta_{\mathrm{p}}$ had a local minimum at the backscatter ratio peak. If this is a real physical effect and not an artifact of measurement or retrieval, it suggests some vertical separation of the volcanic plume, for which we have no ready explanation. The centroid height of the volcanic aerosol plumes descended with time after the Pinatubo eruption (Iwasaka et al., 1995) and after the 2008 Kasatochi eruptions in the Aleutian Islands (Bitar et al., 2010). However, because our observation period was brief, we could not tell whether the height of the aerosol plumes was descending.

\subsection{Aerosol optical depth derived from the backscattering ratio}

Aerosol optical depth (AOD) was calculated as the product of the IBC and $S$. The time series of the AOD at $532 \mathrm{~nm}$ showed three peaks: 0.45 on 11 June, 0.31 on 23 June, and 0.12 on 5 July (Fig. 5). As discussed in Sect. 3.2, the presence of three peaks, and the decrease of the peak value with time, is an indication that the volcanic aerosol plume passed over Lauder three times.

Because the AOD as calculated in this study depends on the lidar ratio value, the appropriateness of the value chosen for that ratio needs to be considered. According to the analysis (Raman method) of Groß et al. (2012), the lidar ratio at $532 \mathrm{~nm}$ for the Eyjafjallajökull eruption was $49 \pm 5 \mathrm{sr}$ (Maisach, Germany), and according to the analysis of Ansmann et al. (2010), it ranged from $55 \pm 5 \mathrm{sr}$ (Maisach) to $60 \pm 5 \mathrm{sr}$ (Leipzig, Germany). Hoffmann et al. (2010) reported that the lidar ratio at $532 \mathrm{~nm}$ for the Kasatochi eruption event was $65 \pm 10 \mathrm{sr}$. We compared the AODs reported above with AODs calculated by a method that does not use the lidar ratio (Uchino et al., 1983). In this method, the 
(a)

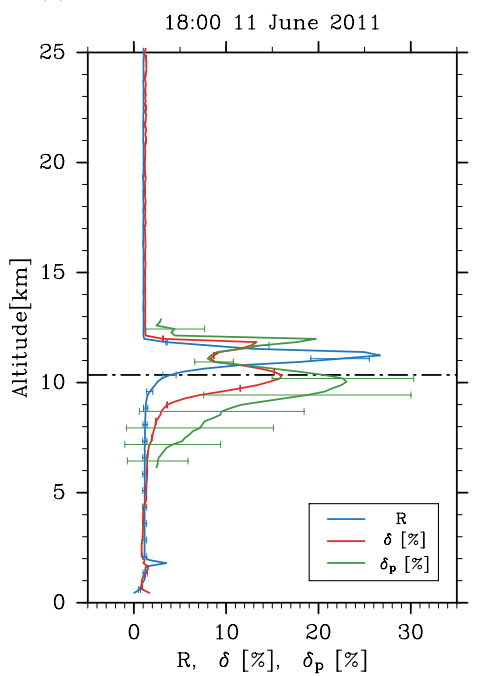

(b)

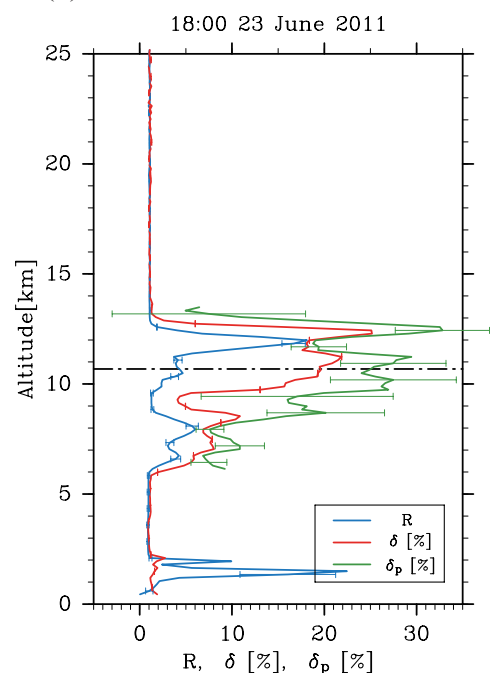

(c)

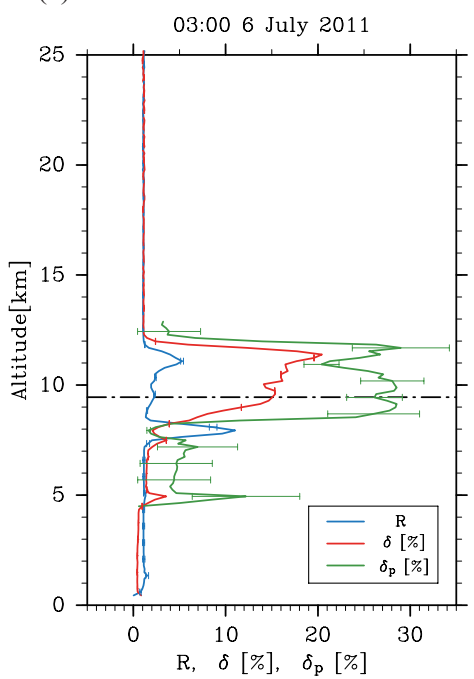

Figure 4. Vertical profiles of the backscattering ratio $R$ (blue line), the total depolarization ratio $\delta$ (red line) and the particle depolarization ratio $\delta_{\mathrm{p}}$ (green line) observed on (a) $11 \mathrm{June}$ at 18:00 LT, (b) $23 \mathrm{June}$ at 18:00 LT, and (c) 6 July at 03:00 LT. The horizontal dot-dash line in each panel shows tropopause height: (a) $10.3 \mathrm{~km}$, (b) $10.6 \mathrm{~km}$ and (c) $9.4 \mathrm{~km}$. The volcanic aerosol layers are indicated by the $R, \delta$ and $\delta$ p peaks above the tropopause height. The error bars are also shown for $R, \delta$, and $\delta_{\mathrm{p}}$ profiles.

transmission $\tau\left(z_{1}, z_{2}\right)$ between altitude $z_{1}$ and $z_{2}$ is

$\tau\left(z_{1}, z_{2}\right)=\frac{z_{2}}{z_{1}}\left[\frac{p\left(z_{2}\right) R\left(z_{1}\right) \beta_{\mathrm{m}}\left(z_{1}\right)}{p\left(z_{1}\right) R\left(z_{2}\right) \beta_{\mathrm{m}}\left(z_{2}\right)}\right]^{1 / 2}$,

where $p(z)$ is the total received signal photon count at altitude $z, \beta_{\mathrm{m}}(z)$ is the atmospheric molecular backscattering coefficient, and $R(z)$ is the backscattering ratio. The transmission can be determined by choosing two altitudes, $z_{1}$ and $z_{2}$, where no aerosols are assumed to exist; therefore, $R\left(z_{1}\right)=R\left(z_{2}\right)=1.0$. For example, the AOD on 11 June as determined by this method was $0.52 \pm 0.08\left(z_{1}=8.4 \mathrm{~km}\right.$ and $z_{2}=12.0 \mathrm{~km}$ ); this AOD value is $13 \%$ larger than the AOD derived from the IBC and $S$. The values of AOD derived by Eq. (6) are 0.17 and 0.12 on 24 June and 6 June, respectively. On average, the AOD derived by IBC was about $20 \%$ smaller than AOD derived by Eq. (6). If the lidar ratio is assumed to be $60 \mathrm{sr}$, AODs will be consistent with each other.

\section{Discussion}

The observed PCCVC particle depolarization ratios $\delta_{\mathrm{p}}$ were large. On 11 June, the maximum $\delta_{\mathrm{p}}$ was $23 \%$; on 23 June, it was $33 \%$; and on 6 July, it was $29 \%$. These large values indicate that the aerosol particles were non-spherical. We then calculated the backscatter-related wavelength exponent $A_{\beta}$ as follows:

$A_{\beta}=-\frac{\ln \left(\beta_{532} / \beta_{1064}\right)}{\ln (532 / 1064)}$,

where $\beta_{532}$ and $\beta_{1064}$ are the backscattering coefficients at $532 \mathrm{~nm}$ and $1064 \mathrm{~nm}$. $A_{\beta}$ provides information about the size distribution of both spherical and non-spherical particles that takes account of the complex dependence of backscatter on particle component size, wavelength, and nonsphericity. $A_{\beta}>2$ indicates relatively smaller particles (radius $\leq 0.5 \mu \mathrm{m}$ ), and $A_{\beta}$ around zero indicates larger particles (radius $\geq 0.5 \mu \mathrm{m}$ ) (Kaufman et al., 1994; Schuster et al., 2006). For background stratospheric aerosols, $A_{\beta}$ is about 2.0 (Shibata et al., 1984; Hofmann et al., 2009); for cloud layers $A_{\beta}$ is about -0.2 to 0.0 (Kamei et al., 2006; Mona et al., 2012), and for volcanic ash $A_{\beta}$ is about 1.0 (Ansmann et al., 2012).

Figure 6a displays the vertical profiles of $R, \delta$ and $\delta_{\mathrm{p}}$ at $532 \mathrm{~nm}$, and Fig. 6b shows the vertical profiles of $R$ at $532 \mathrm{~nm}$ and $1064 \mathrm{~nm}$ and of $A_{\beta}$ at $532 \mathrm{~nm} / 1064 \mathrm{~nm}$, on 13 June. The peak of $R$ was below the tropopause, but we infer that this represents the volcanic layer because its average $A_{\beta}$ at $11-13 \mathrm{~km}$ altitude was 0.92 , whereas that of the stratospheric background aerosols at $13-15 \mathrm{~km}$ was 2.54 , and the mean value of cirrus clouds at $8-9.5 \mathrm{~km}$ was $1.29 \times 10^{-2}$. Although the stratospheric aerosol $A_{\beta}$ value at $13-15 \mathrm{~km}$ is a little larger than the literature value, the $A_{\beta}$ values of the volcanic aerosols and cirrus clouds are consistent with value reported by previous studies (Kamei et al., 2006; Mona et al., 2012; Ansmann et al., 2012). This result indicates that it should be possible to distinguish between a volcanic aerosol layer and underlying cirrus clouds by using the vertical profile of $A_{\beta}$. Unfortunately, because there were optically thick clouds under the volcanic aerosol layers and the vertical backscattering coefficient at $1064 \mathrm{~nm}$ were very noisy, we were not able to apply this method to distinguish the aerosols and cirrus clouds on the other days. 


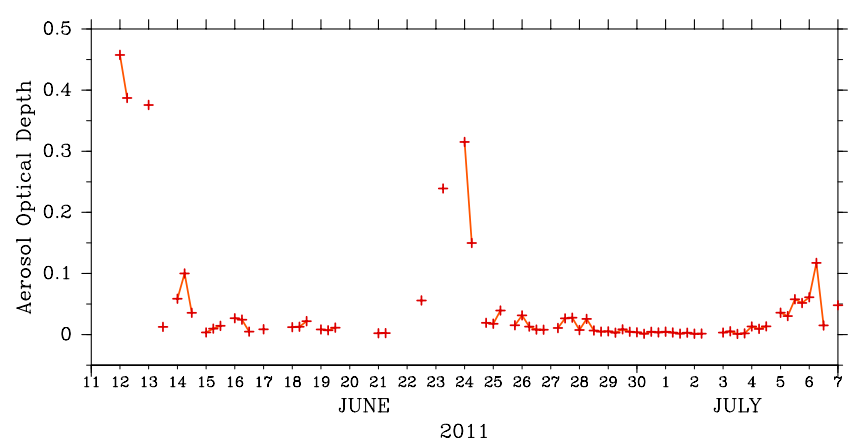

Figure 5. Temporal variation of the stratospheric AOD over Lauder from 11 June to 6 July 2011. Three AOD peaks occurred of 0.45 on 11 June, 0.31 on 23 June and 0.12 on 6 July.

It is possible to use $A_{\beta}, \delta$ and $\delta_{\mathrm{p}}$ derived from lidar measurement to determine approximately the proportions of sulfur acid aerosols and the ash particles. However, it is not possible to determine the absolute quantity of these particles. Typically, non-spherical and larger particles are volcanic ash, whereas spherical and smaller particles are sulfuric acid aerosols. As mentioned in Sect. 3, the finding that the total and particle depolarization ratios of the PCCVC volcanic aerosols were larger than $20 \%$ suggests that the volcanic plume included many non-spherical and large particles. Therefore, we concluded that the dominant component of the plume observed over Lauder was volcanic ash.

Similarly, for aerosols from the eruption of Eyjafjallajökull, the total depolarization ratios were 35-40\% (Ansmann et al., 2010; Gasteiger et al., 2011). In contrast, the Kasatochi ratios were 1.5-5.0\% (Hoffmann et al., 2010) and the ratios for aerosols from the eruption of Nabro volcano in Eritrea in 2011 were $\delta=1-2 \%$ and $\delta_{\mathrm{p}}=4-7 \%$ (Uchino et al., 2012). In the case of the eruption of Eyjafjallajökull, Ansmann et al. (2011) reported that sulfate aerosols originating from volcanic $\mathrm{SO}_{2}$ plumes contributed about $50 \%$ of the particle mass. Miffre et al. (2011) used the volcanic ash particle depolarization ratio $\delta_{\mathrm{p}}=40 \pm 0.2 \%$ obtained from laboratory measurements performed by Muñoz et al. (2004) to determine the composition of the Eyjafjallajökull plume.

Recent studies have provided estimates of $\mathrm{SO}_{2}$ emission from several eruption events. Karagulian et al. (2010) estimated the total mass of $\mathrm{SO}_{2}$ ejected by the Kasatochi eruption to be $1.7 \mathrm{Tg}$, based on the IASI high-spectral-resolution infrared radiance measurements. Haywood et al. (2010) estimated that $1.2 \mathrm{Tg}$ of $\mathrm{SO}_{2}$ was ejected by the Sarychev (Kuril Islands) eruption in June 2009. Clarisse et al. (2012), using IASI data, reported that $1.5 \mathrm{Tg}$ of $\mathrm{SO}_{2}$ was ejected by the Nabro volcano, and $0.25 \mathrm{Tg}$ by the PCCVC eruption. Because less $\mathrm{SO}_{2}$ was ejected by the eruption of PCCVC compared with the amounts ejected by the eruptions of Nabro and Kasatochi, the tephra fraction of the PCCVC plume was greater, and its depolarization ratios were larger.
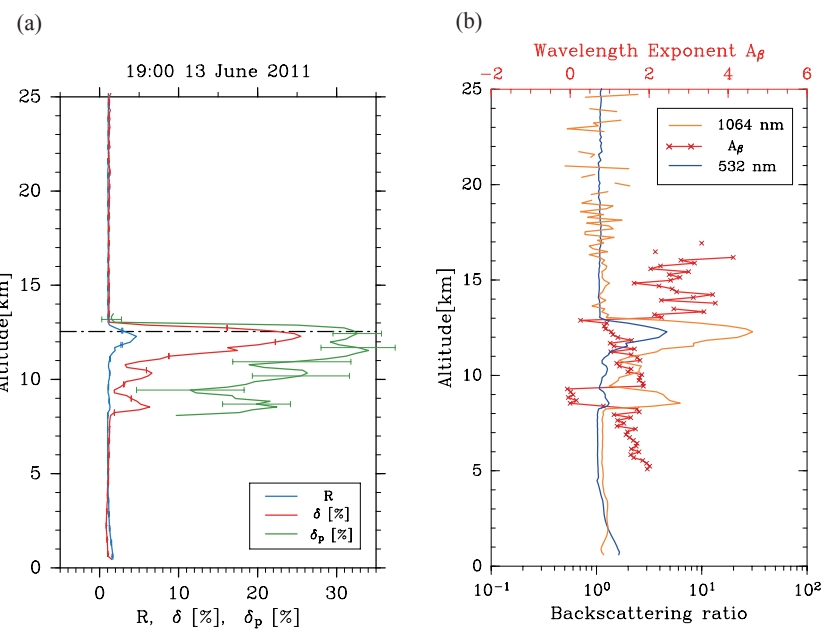

Figure 6. (a) Vertical profiles of the backscattering ratio $R$ (blue line), the total depolarization ratio $\delta$ (red line), and the particle depolarization ratio $\delta_{\mathrm{p}}$ (green line) at $532 \mathrm{~nm}$ on 13 June. The horizontal dot-dash line in left panel (a) shows tropopause height. (b) Vertical profiles of the backscattering ratio at $532 \mathrm{~nm}$ (blue line), the backscattering ratio at $1064 \mathrm{~nm}$ (orange line), and the wavelength exponent of the backscattering ratios $\left(A_{\beta}\right)$ at $1064 \mathrm{~nm} / 532 \mathrm{~nm}$ (red line) on 13 June.

We next estimated the influence of the PCCVC volcanic ash particles on the column-averaged dry air mole fraction of carbon dioxide $\left(\mathrm{XCO}_{2}\right)$ determined by GOSAT. When the GOSAT $\mathrm{XCO}_{2}$ is retrieved by using the $1.6 \mu \mathrm{m}$ band without taking account of volcanic ash particles in the upper troposphere and lower stratosphere, the negative bias of $\mathrm{XCO}_{2}$ is estimated to be $2 \%$ for an AOD of 0.4 at $532 \mathrm{~nm}$ and surface albedo of 0.2 at Lauder based on MODIS band 2 (Ota et al., 2008).

\section{Summary}

On 4 June 2011, the Puyehue-Cordón Caulle volcanic complex $\left(40.59^{\circ} \mathrm{S}, 72.11^{\circ} \mathrm{W}\right)$ in Chile erupted and the volcanic plume passed over Lauder in New Zealand. Because the VAAC at Wellington had forecast that the aerosol plume would pass over New Zealand, we started continuous lidar observations on 11 June. On the same day, we detected the PCCVC volcanic aerosol layer from the profiles of the backscattering ratio $R$ and the depolarization ratio $\delta$ at $532 \mathrm{~nm}$. This observational result was confirmed by a forward trajectory analysis done by using METEX and some satellite data (from the MODIS, OMI and IASI instruments). We found that the volcanic aerosol layer peak passed over Lauder three times from 11 June to 6 July at intervals of 10-12 days. The maximum $R$ value on 11 June, immediately after the eruption, was 27 at $11.2 \mathrm{~km}$, and the AOD was 0.45 . This $R$ value is much larger than the maximum $R$ value of 2.0-3.5 observed at Saga and Tsukuba, Japan, for 
the Nabro volcano, which erupted on 12 June 2011 (Uchino et al., 2012). On 11 June, when the continuous lidar observation started, the maximum value of $\delta$ was $16 \%$ and that of $\delta_{\mathrm{p}}$ was $23 \%$. On 6 July, at the end of the period of continuous lidar observations, the maximum value of $\delta$ was $20 \%$, and that of $\delta_{\mathrm{p}}$ was $29 \%$. Thus, $\delta_{\mathrm{p}}$ remained at $20-30 \%$ over the entire observation period, and even 1 month after the eruption the depolarization ratio had not decreased. This result indicates that the major component of the PCCVC volcanic aerosol layers was non-spherical particles.

The backscatter-related wavelength exponent of the PCCVC volcanic aerosols at $1064 / 532 \mathrm{~nm}$ was 0.9 at $11-13 \mathrm{~km}$ altitude; this value indicates that the PCCVC volcanic aerosols were composed of large particles. According to Ansmann et al. (2012), the wavelength exponents of the Eyjafjallajökull volcanic aerosols were $1.12-1.19$. The wavelength exponents of the Kasatochi eruption aerosols were 0.5-1.5 (Tesche et al., 2010). The lidar observations at Lauder showed that the PCCVC volcanic aerosol layers contained non-spherical and larger particles. These results agree with the findings of previous studies, which reported that the volcanic plume of the PCCVC eruption contained less $\mathrm{SO}_{2}$ than the plumes from the Kasatochi and Nabro eruptions (Karagulian et al., 2010; Clarisse et al., 2012).

Acknowledgements. This research was supported in part by the Environment Research and Technology Development Fund (2A-1102) of the Ministry of the Environment, Japan. The author wishes to thank the editor for helpful many comments.

Edited by: G. Vaughan

\section{References}

Alados-Arboledas, L., Olmo, F. J., Ohvril, H. O., Teral, H., Arak, M., and Teral, K.: Evolution of solar radiative effects of Mount Pinatubo at ground level, Tellus B, 49, 190-198, 1997.

Ansmann, A., Tesche, M., Groß, S., Freudenthaler, V., Seifert, P., Hiebsch, A., Schmidt, J., Wandinger, U., Mattis, I., Müller, D., and Wiegner, M.: The 16 April 2010 major volcanic ash plume over central Europe: EARLINET lidar and AERONET photometer observations at Leipzig and Munich, Germany, Geophys. Res. Lett., 37, L13810, doi:10.1029/2010GL043809, 2010.

Ansmann, A., Tesche, M., Seifert, P., Groß, S., Freudenthaler, V., Apituley, A., Wilson, K. M., Serikov, I., Linnú, H., Heinold, B., Hiebsch, A., Schnell, F., Schmidt, J., Mattis, I., Wandinger, U., and Wiegner, M.: Ash and fine-mode particle mass profiles from EARLINET-AERONET observations over central Europe after the eruptions of the Eyjafjallajökull volcano in 2010, J. Geophys. Res., 116, D00U02, doi:10.1029/2010JD015567, 2011.

Ansmann, A., Seifert, P., Tesche, M., and Wandinger, U.: Profiling of fine and coarse particle mass: case studies of Saharan dust and Eyjafjallajökull/Grimsvötn volcanic plumes, Atmos. Chem. Phys., 12, 9399-9415, doi:10.5194/acp-12-9399-2012, 2012.
Bernard, A. and Rose, W. I.: The injection of sulfuric acid aerosols in the stratosphere by El Chichon Volcano and its related hazards to the international air traffic, Nat. Hazards, 3, 59-67, 1990.

Bitar, L., Duck, T. J., Kristiansen, N. I., Stohl, A., and Beauchamp, S.: Lidar observations of Kasatochi volcano aerosols in the troposphere and stratosphere, J. Geophys. Res., 115, D00L13, doi:10.1029/2009JD013650, 2010.

Bluth, G. J. S., Doiron, S. D., Schnetzler, S. C., Krueger, A. J., and Walter, L. S.: Global tracking of the $\mathrm{SO}_{2}$ clouds from the June 1991 Mount Pinatubo eruptions, Geophys. Res. Lett., 19, 151-154, 1992.

Bucholtz, A.: Rayleigh-scattering calculations for the terrestrial atmosphere, Appl. Opt., 34, 2765-2773, 1995.

Clarisse, L., Hurtmans, D., Clerbaux, C., Hadji-Lazaro, J., Ngadi, Y., and Coheur, P.-F.: Retrieval of sulphur dioxide from the infrared atmospheric sounding interferometer (IASI), Atmos. Meas. Tech., 5, 581-594, doi:10.5194/amt-5-581-2012, 2012.

Deshler, T.: A review of global stratospheric aerosol: Measurements, importance, life cycle, and stratospheric aerosol, Atmos. Res., 90, 223-232, 2008.

Durant, A. J., Shaw, R. A., Rose, W. I., Mi, Y., and Ernst, G. G. J.: Ice nucleation and overseeding of ice in volcanic clouds, J. Geophys. Res., 113, D09206, doi:10.1029/2007JD009064, 2008.

Dzierma, Y. and Wehrmann, H.: On the likelihood of future eruptions in the Chilean Southern Volcanic Zone: interpreting the past century's eruption record based on statistical analyses, And. Geol., 39, 380-393, 2012.

Fernald, F. G.: Analysis of atmospheric lidar observations: some comments, Appl. Opt., 23, 5, 652-653, 1984.

Gasteiger, J., Groß, S., Freudenthaler, V., and Wiegner, M.: Volcanic ash from Iceland over Munich: Mass concentration retrieved from ground-based remote sensing measurements, Atmos. Chem. Phys., 11, 2209-2223, doi:10.5194/acp-11-22092011, 2011.

Groß, S., Freudenthaler, V., Wiegner, M., Gasteiger, J., Geiß, A., and Schnell, F.: Dual-wavelength linear depolarization ratio of volcanic aerosols: Lidar measurements of the Eyjafjallajökull plume over Maisach, Germany, Atmos. Environ., 48, 85-96, 2012.

Haywood, J. M., Jones, A., Clarisse, L., Bourassa, A., Barnes, J., Telford, P., Bellouin, N., Boucher, O., Agnew, P., Clerbaux, C., Coheur, P., Degenstein, D., and Braesicke, P.: Observations of the eruption of the Sarychev volcano and simulations using the HadGEM2 climate model, J. Geophys. Res., 115, D21212, doi:10.1029/2010JD014447, 2010.

Hofmann, D., Barnes, J., O’Neill, M., Trudeau, M., and Neely, R.: Increase in background stratospheric aerosol observed with lidar at Mauna Loa Observatory and Boulder, Colorado, Geophys. Res. Lett., 36, L15808, doi:10.1029/2009GL039008, 2009.

Hoffmann, A., Ritter, C., Stock, M., Maturilli, M., Eckhardt, S., Herber, A., and Neuber, R.: Lidar measurements of the Kasatochi aerosol plume in August and September 2008 in Ny-Alesund, Spitsbergen, J. Geophys. Res., 115, D00L12, doi:10.1029/2009JD013039, 2010.

Iwasaka, Y., Shibata, T., Hayashi, M., Nagatani, M., Ojio, T., Adachi, H., Matsunaga, K., Osada, K., Mori, I., Fujiwara, M., Akiyoshi, E., Shiraishi, K., Yamazaki, K., Kondoh, K., and Nakane, H.: Lidar measurements at Alaska, 1991-1994, 
Pinatubo volcanic effect on stratospheric aerosol layer, Rev. Laser Engin., 23, 2, 166-170, 1995.

Kalnay, E., Kanamitsu, M., Kistler, R., Collins, W., Deaven, D., Gandin, L., Iredell, M., Saha, S., White, G., Woollen, J., Zhu, Y., Leetmaa, A., Reynolds, R., Chelliah, M., Ebisuzaki, W., Higgins, W., Janowiak, J., Mo, K. C., Ropelewski, C., Wang, J., Jenne, R., and Joseph, D.: The NCEP/NCAR 40-Year Reanalysis Project, Bull. Amer. Meteor. Soc., 77, 437-471, 1996.

Kamei, A., Sugimoto, N., Matsui, I., Shimizu, A., and Shibata, T.: Volcanic aerosol layer observed by shipboard lidar over the tropical western Pacific, SOLA, 2, 1-4, 2006.

Karagulian, F., Clarisse, L., Clerbaux, C., Prata, A. J., Hurtmans, D., and Coheur, P. F.: Detection of volcanic $\mathrm{SO}_{2}$, ash, and $\mathrm{H}_{2} \mathrm{SO}_{4}$ using the Infrared Atmospheric Sounding Interferometer, J. Geophys. Res., 115, D00L02, doi:10.1029/2009JD012786, 2010.

Kaufman, Y. J., Gitelson, A., Karnieli, A., Ganor, E., Fraser, R. S., Nakajima, T., Mattoo, S., and Holben, B. N.: Size distribution and scattering phase function of aerosol particles retrieved from sky brightness measurements, J. Geophys. Res., 99, 10341-0356, 1994.

Klüser, L., Erbertseder, T., and Meyer-Arnek, J.: Observation of volcanic ash from Puyehue Cordón Caulle with IASI, Atmos. Meas. Tech., 6, 35-46, doi:10.5194/amt-6-35-2013, 2013.

Lara, L. E., Moreno-Roa, H., and Naranjo, J. A.: Rhyodacitic fissure eruption in Southern Andes (Cordón Caulle; $40.5^{\circ} \mathrm{S}$ ) after the 1960 (Mw:9.5) Chilean earthquake: a structural interpretation, J. Volcanol. Geotherm. Res., 138, 127-138, 2004.

Lathem, T. L., Kumar, P., Nenes, A., Dufek, J., Sokolik, I. N., Trail, M., and Russell, A.: Hygroscopic properties of volcanic ash, Geophys. Res. Lett., 38, 11, L11802, doi:10.1029/2011GL047298, 2011.

McCormick, M. P., Thomason, L. W., and Trepte, C. R.: Atmospheric effects of the Mt Pinatubo eruption, Nature, 373, 399-404, 1995.

Miffre, A., David, G., Thomas, B., Abou-Chacra, M., and Rairoux, P.: Interpretation of accurate uv polarization lidar measurements: application to volcanic ash number concentration retrieval, J. Atmos. Oceanic Technol., 29, 558-568, 2011.

Minnis, P., Harrison, E. F., Stowe, L. L., Gibson, G. G., Denn, F. M., Doelling, D. R., and Smith Jr., W. L.: Radiative climate forcing by the Mount Pinatubo eruption, Science, 259, 1411-1415, 1993.

Mona, L., Amodeo, A., D'Amico, G., Giunta, A., Madonna, F., and Pappalardo, G.: Multi-wavelength Raman lidar observations of the Eyjafjallajökull volcanic cloud over Potenza, Southern Italy, Atmos. Chem. Phys., 12, 2229-2244, doi:10.5194/acp-12-22292012, 2012.

Muñoz, O., Volten, H., Hovenier, J. W., Veihelmann, B., van der Zande, W. J., Waters, L. B. F. M., and Rose, W. I.: Scattering matrices of volcanic ash particles of Mount St. Helens, Redoubt, and Mount Spurr Volcanoes, J. Geophys. Res., 109, D16201, doi:10.1029/2004JD004684, 2004.

Nagai, T., Sakai, T., Uchino, O., Morino, I., Yokota, T., and Liley, B.: Lidar observations of clouds and aerosols over Lauder in the Southern Hemisphere for GOSAT validation, Proceedings of the 46th spring conference of the Remote Sensing Society of Japan, 2009

Nagai, T., Liley, B., Sakai, T., Shibata, T., and Uchino, O.: Postpinatubo evolution and subsequent trend of the stratospheric aerosol layer observed by mid-latitude lidars in both hemispheres, SOLA, 6, 69-72, 2010.

Newhall, C. G. and Self, S.: The volcanic explosivity index (VEI) an estimate of explosive magnitude for historical volcanism, J. Geophys. Res., 87, 1231-1238, doi:10.1029/JC087iC02p01231, 1982.

Ota, Y., Yoshida, Y., and Yokota, T.: Study of retrieving column amount of carbon dioxide from satellite-based near-infrared observation of solar scattered light in clear sky condition - error estimation and optimization of vertical pressure grid, J. Remote Sens. Jpn., 28, 152-160, 2008 (in Japanese).

Raga, G. B., Baumgardner, D., Ulke, A. G., Brizuela, M. T., and Kucienska, B.: The environmental impact of the Puyehue-Cordón Caulle 2011 volcanic eruption on Buenos Aires, Nat. Hazards Earth Syst. Sci., 13, 2319-2330, doi:10.5194/nhess-13-23192013, 2013.

Robock, A.: Volcanic eruptions and climate, Rev. Geophys., 38, 191-219, 2000.

Sakai, T., Nagai, T., Nakazato, M., Mano, Y., and Matsumura, T.: Ice clouds and Asian dust studied with lidar measurements of particle extinction-to-backscatter ratio, particle depolarization, and water-vapor mixing ratio over Tsukuba, Appl. Opt., 42, 7103-7116, 2003.

Sassen, K.: The polarization lidar technique for cloud research: A review and current assessment, Bull. Amer. Meteor. Soc., 72, 1848-1866, 1991.

Schuster, G. L., Dubovik, O., and Holben, B. N.: Angstrom exponent and bimodal aerosol size distributions, J. Geophys. Res, 111, D07207, doi:10.1029/2005JD006328, 2006.

Shibata, T., Fujiwara, M., and Hirono, M.: The El Chichon volcanic cloud in the stratosphere: lidar observation at Fukuoka and numerical simulation, J. Atmos. Terr. Phys., 46, 1121-1146, 1984.

Solomon, S., Daniel, J. S., Neely III, R. R., Vernier, J.-P., Dutton, E. G., and Thomaso, L. W.: The persistently variable "background" stratospheric aerosol layer and global climate change, Science, 333, 866-870, doi:10.1126/science.1206027, 2011.

Tesche, M., Ansmann, A., Hiebsch, A., Mattis, I., Schmidt, J., Seifert, P., and Wandinger, U.: Lidar observations of the Eyjafjallajökull volcanic ash plume at Leipzig, Germany, Proc. SPIE, 7832, 78320L-1, doi:10.1117/12.868516, 2010.

Trickl, T., Giehl, H., Jäger, H., and Vogelmann, H.: 35 yr of stratospheric aerosol measurements at Garmisch-Partenkirchen: from Fuego to Eyjafjallajökull, and beyond, Atmos. Chem. Phys., 13, 5205-5225, doi:10.5194/acp-13-5205-2013, 2013.

Uchino, O., Tokunaga, M., Seki, K., Maeda, M., Naito, K., and Takahashi, K.: Lidar measurement of stratospheric transmission at a wavelength of $340 \mathrm{~nm}$ after the eruption of El Chichon, J. Atmos. Terr. Phys., 45, 12, 849-850, 1983.

Uchino, O., Nagai, T., Fujimoto, T., Matthews, W. A., and Orange, J.: Extensive lidar observations of the Pinatubo aerosol layers at Tsukuba $\left(36.1^{\circ} \mathrm{N}\right)$, Naha $\left(26.2^{\circ} \mathrm{N}\right)$, Japan and Lauder $\left(45.0^{\circ} \mathrm{S}\right)$, New Zealand, Geophys. Res. Lett., 22, 57-60, 1995.

Uchino, O., Sakai, T., Nagai, T., Nakamae, K., Morino, I., Arai, K., Okumura, H., Takubo, S., Kawasaki, T., Mano, Y., Matsunaga, T., and Yokota, T.: On recent (2008-2012) stratospheric aerosols observed by lidar over Japan, Atmos. Chem. Phys., 12, 11975-11984, doi:10.5194/acp-12-11975-2012, 2012.

Vernier, J.-P., Thomason, L. W., Pommereau, J.-P., Bourassa, A., Pelon, J., Garnier, A., Hauchecorne, A., Blanot, L., Trepte, 
C., Degenstein, D., and Vargas, F.: Major influence of tropical volcanic eruptions on the stratospheric aerosol layer during the last decade, Geophys. Res. Lett., 38, 12, L12807, doi:10.1029/2011GL047563, 2011.

Wiegner, M., Gasteiger, J., Groß, S., Schnell, F., Freudenthaler, V., and Forkel, R.: Characterization of the Eyjafjallajökull ashplume: potential of lidar remote sensing, Phys. Chem. Earth, 45/46, 79-86, 2012.

World Meteorological Organization (WMO): Definition of the tropopause, WMO Bull., 6, 136-140, 1957.
Wu, P.-M., Okada, K., Tanaka, T., Sasaki, T., Nagai, T., Fujimoto, T., and Uchino, O.: Balloon observation of stratospheric aerosols over Tsukuba, Japan Two years after the Pinatubo volcanic eruption, J. Meteor. Soc. Jpn., 72, 475-480, 1994.

Zhao, J., Turco, R. P., and Owen, O. B.: A model simulation of Pinatubo volcanic aerosols in the stratosphere, J. Geophys. Res., 100, 7315-7328, 1995. 